\title{
Oral Squamous Cell Carcinoma Associated with Arsenic Exposure: A Case Series from Argentina
}

\author{
Carcinoma Oral de Células Escamosas Asociado con la \\ Exposición al Arsénico: Una Serie de Casos de Argentina
}

\author{
Leonardi, Nicolás'; Gilligan, Gerardo Marcelo² \& Panico, Rene Luis ${ }^{3}$
}

LEONARDI, N.; GILLIGAN G, M. \& PANICO R. L. Oral squamous cell carcinoma associated with arsenic exposure: A case series from Argentina. Int. J. Odontostomat., 14(4):596-601, 2020.

\begin{abstract}
Many areas of South America are directly affected by Arsenic (As) contaminated groundwater. A high percentage of the water samples taken in multiple areas of Argentina had As concentrations above the WHO level recommended guidelines. This condition was previously associated with an increased risk of chronic diseases, including different cancers. Long-term As exposure was proposed as a risk factor for Oral Squamous Cell Carcinoma (OSCC). The aim of this study is to present a series cases of Argentine patients diagnosed with OSCC who have consumed water contaminated with As for more than 10 years. Clinical data were obtained from the archive of Clinical Records Histories of the Oral Medicine Department of the Dentistry School, Universidad Nacional de Córdoba and Universidad Católica de Córdoba, Argentina. 15 cases of OSCC were included. The male: female sex ratio was 2:1. The average age was 66 years (31-89 years). Regarding location, the gum or edentulous alveolar ridge was the most prevalent site $(6 / 15 ; 40 \%)$, followed by the tongue margin. The average years of exposure to arsenical waters were 24 years (13- 40 years of exposure). The majority of the presented cases were non drinkers non smokers. $60 \%$ of the tumors were diagnosed at advanced stages. the epidemiological studies carried out in As-contaminated areas that address oral cancer should always incorporate the record of variables related to As exposure. Patients who live or lived at As-contaminated areas must be regularly followed up for early diagnosis of potentially malignant or malignant lesions. The high frequency of gum cancer among these cases, should raise awareness of periodontic specialists to perform a careful and thorough periodontal examination.
\end{abstract}

KEY WORDS: arsenic, oral squamous cell carcinoma, risk factors, pollution, groundwater.

\section{INTRODUCTION}

Arsenic (As) is an environmental pollutant that causes damage to the health of millions of people worldwide. Around 70 countries and 137 million people are directly affected by the consumption of contaminated groundwater. Bangladesh and West Bengal in India are the most affected areas in the world (Mukherjee et al., 2006; Cardoso et al., 2018). Also, many areas of South America have the same problem. Four million people in Argentina are exposed to As contamination from the drinking water in several centernorthern provinces. In 2015, a high percentage of the water samples taken in multiple areas of Argentina had As concentrations above the $\mathrm{WHO}$ level guidelines. This condition in Argentina is associated with an increased risk of chronic diseases, including different cancers (skin, liver, etc.) (Bardach et al., 2015).

As was classified by the International Agency for Research of Cancer (IARC) as a human carcinogenic agent. The World Health Organization (WHO) recommends a value for drinking water of 10 $\mathrm{mg} / \mathrm{L}$ (IARC Working Group on the Evaluation of Carcinogenic Risks to Humans, 2012). Different studies carried out in 1888 identified several diseases associated with As contamination. Among them, it was observed that patients who consumed water in arsenic areas, presented cutaneous keratoses, hyperpigmentations, and skin cancer. Furthermore, it

\footnotetext{
${ }^{1}$ Professor Oral Medicine Department - Dentistry School, Universidad Católica de Córdoba, Argentina.

${ }_{2}^{2}$ Assistant Professor Oral Medicine Department, Dentistry School, Universidad Nacional de Córdoba, Argentina.

${ }^{3}$ Head Professor Oral Medicine Department, Dentistry School, Universidad Católica de Córdoba y Universidad Nacional de Córdoba, Argentina.
} 
was reported frequent manifestations of chronic arsenicism such as peripheral neuropathies; chronic lung diseases; hepatomegaly; peripheral vascular disease, gangrenous disorders of the lower limbs and diabetes mellitus (Carabantes \& de Fernicola, 2003; Mondal et al., 2010; Banerjee \& Giri, 2014).

In 1913, two Argentinian patients reported symptoms of As poisoning. Both cases were identified and considered as accidental events. However, the number of cases increased in specific areas and those systemic conditions associated with As were called as "Bell Ville disease", as this town was the place with the highest number of cases. Bell Ville is a city located in the central region of Argentina (Córdoba province). In some adjacent rural regions, as water levels were above $1000 \mu \mathrm{g} / \mathrm{L}$. In 1917, Endemic Regional Chronic Hydroarsenicism (ERCH) was presented as an entity or syndromic condition that could involve multiple systemic lesions and symptoms (Carabantes \& de Fernicola, 2003).

Although the epidemiological evidence shows an association between inorganic As in drinking groundwater and an increased risk of skin, lung and bladder cancers, there are inconsistencies with experimental results, especially in animal researches. Some of the involved carcinogenic mechanisms associated with the chronic consumption of as are related to an increase of oxidative stress, altered DNA repair, DNA methylation, p53 suppression, etc (States, 2015; Cardoso et al.). Some studies from Southeast Asia (large areas of arsenic contaminated waters) described an impact on the prevalence of Oral Squamous Cell Carcinoma (OSCC) (Park et al., 2008; Pal et al., 2017). Chronic exposure to different sources of As contamination is considered an environmental risk factor for OSCC (Carrica et al., 1999). However, there is scarce scientific evidence of the clinical findings among these As-related cancers. The aim of this study is to present a series of clinical cases of Argentine patients diagnosed with OSCC who have consumed water contaminated with As for more than 10 years, emphasizing the risk factors and clinical variables associated with the disease.

\section{MATERIAL AND METHOD}

Clinical data were obtained from the archive of Clinical Records Histories of the Oral Medicine Department of the Dentistry School, Universidad Na- cional de Córdoba and Universidad Católica de Córdoba, Argentina, respectively. In this study 156 clinical records of patients attended in both services with histopathological diagnosis of OSCC were examined. Of the 156, $15(9.61 \%)$ met the inclusion criteria in relation to exposure to arsenical waters (at least 10 years of water consumption). The following variables were also recorded: sex, age, geographic area of residence, years of consumption of arsenic water, accumulated consumption of tobacco, alcohol, mate, presence of chronic mechanical irritation (CMI) according to Piemonte et al. (2010) criteria, location and size of the lesion according to TNM classification criteria (Hoffmann \& Tribius, 2019).

\section{RESULTS - CASE PRESENTATION}

Of the fifteen cases included in this case-series, the male: female sex ratio was $2: 1$. The average age was 66 years (31-89 years). Regarding location, the gum or edentulous alveolar ridge was the most prevalent site $(6 / 15 ; 40 \%$ - Fig. 1$)$, followed by the tongue margin (5/15; $33 \%$ - Fig. 2$)$, buccal mucosa (2; $13.33 \%)$, soft palate $(1 ; 6.66 \%)$ and finally the floor of the mouth $(1 ; 6.66 \%)$. The average years of exposure to arsenical waters were 24 years (13-40 years of exposure) (Table I).

Concerning the traditional risk factors for OSCC recorded, $54 \%$ of patients reported no history of smoking or drinking. The remaining $46 \%$ were chronic smokers and 5 (33\%) were heavy drinkers. Regarding the presence of $\mathrm{CMI}$ or traumatizing agents, $46 \%$ were associated with several traumatic factors (dental, prosthetic and / or functional). $60 \%$ of the tumors were diagnosed at advanced stages (T3 and T4 and some degree of $\mathrm{N}$ ). There was only one case of a Micro invasive carcinoma, diagnosed in a clinical context of a precancerous lesion of Multifocal Proliferative Leukoplakia. Figure 3 shows the geographical distribution of the analyzed cases across the Argentine map.

\section{DISCUSSION}

The geographical regions with the highest frequency of arsenic waters in Argentina correspond to the provinces of Córdoba (southern, eastern and southeastern areas), La Pampa, Santa Fe, Chaco, 

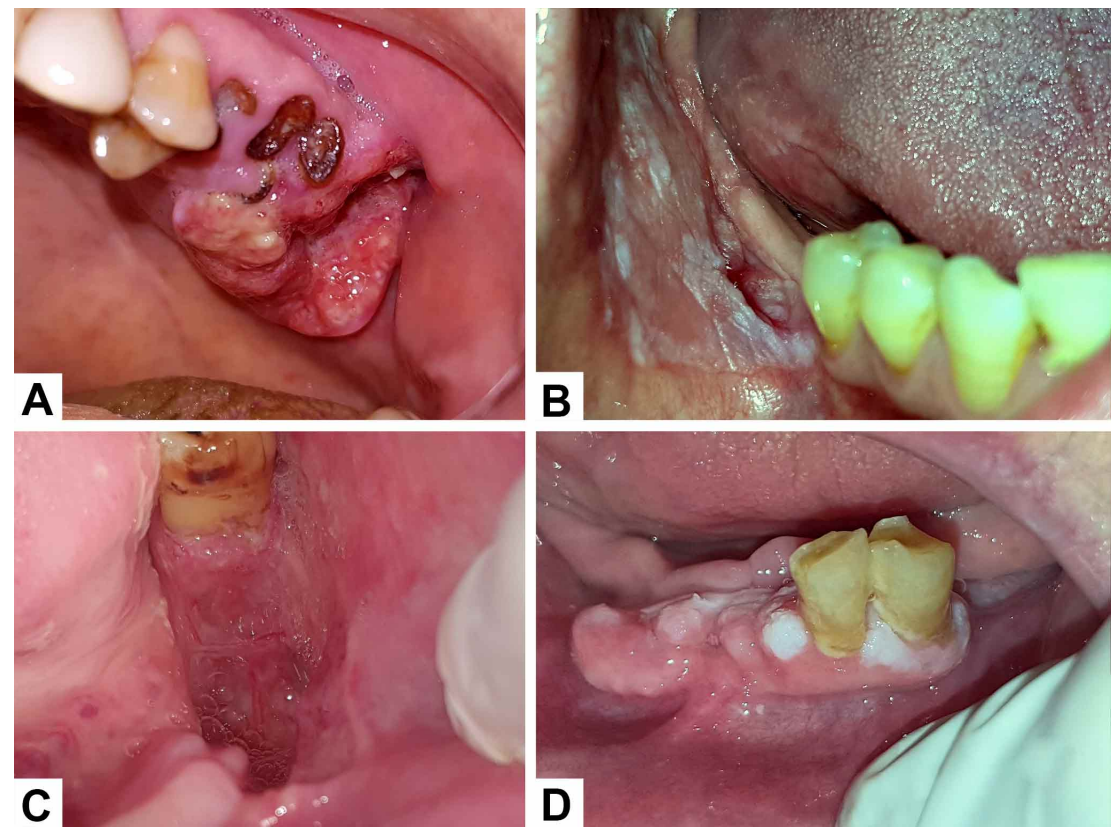

Fig. 1. A. Tumor located on the upper gingiva associated with severe periodontal disease in a patient who, for 40 years, consumed groundwater contaminated with As (Santiago del Estero, Argentina). B. Male from the city of Bell Ville, Córdoba; without classic risk factors for Oral Cancer. A red patch located on the retromolar area was noted, arising in a clinical context of a Multifocal Proliferative Leukoplakia. An incisional biopsy was performed with the histopathological diagnosis of Microinvasive Oral squamous Cell Carcinoma. C. Female patient with a carcinomatous ulcer that generated the tooth exfoliation. The patient did not present classic risk factors, but she presented severe periodontal disease. It was reported that for more than 20 years the patient consumed groundwater in an arsenic contaminated area of Argentina. D. Female patient who developed multiple gingival foci of Verrucous Carcinoma OSCC. No history of smoking or drinking was reported. Exposure to As for over 20 years.
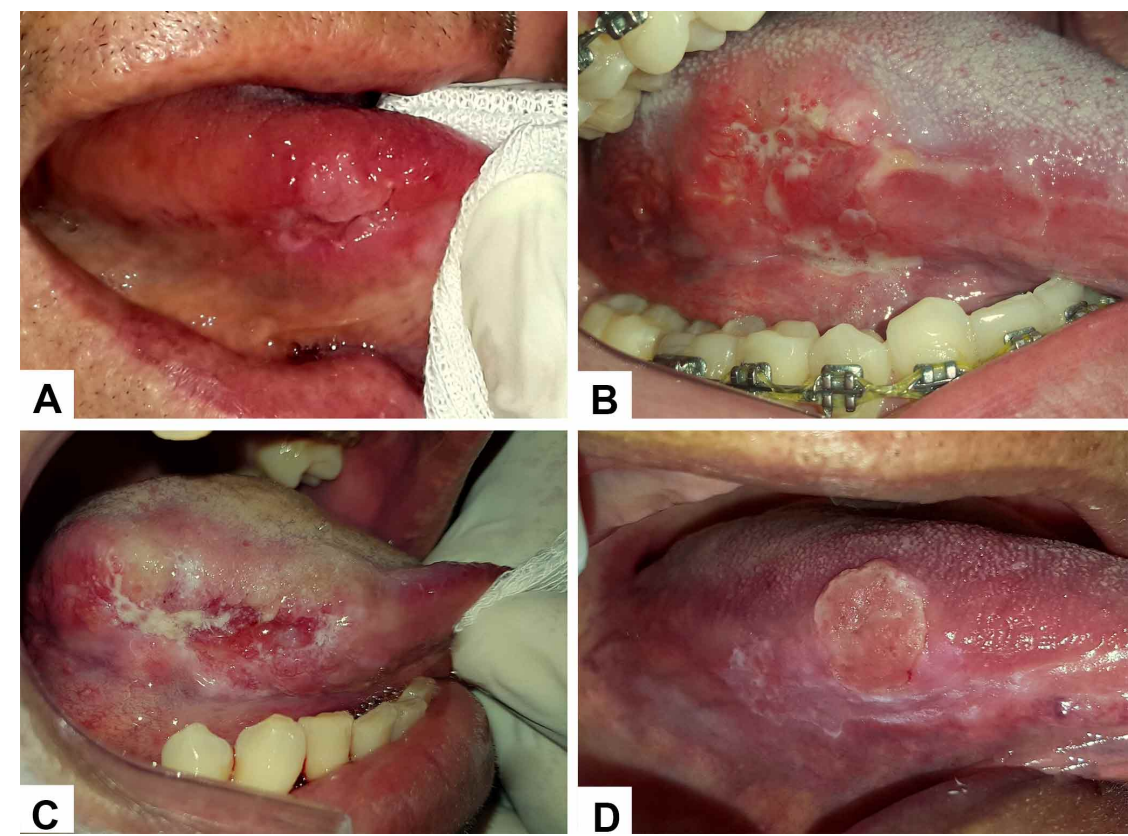

Salta, San Luis, Buenos Aires (some districts of northern and northeastern areas) and Santiago del Estero. However, the whole record of the affected areas is still incomplete (Piemonte, 2015). Carrica et al., suggested that there is an increased risk of developing OSCC, leukoplakia and lip keratosis among patients who consumed As-contaminated water for more than 10 years and that lived in the above mentioned Cordoba's contaminated subregions. In the case-series presented here, the average exposure time to As water was 24 years (minimum of consumption of 13 years); according to Carrica's study.

As was previously proposed as a human co-carcinogen due to the ability to induce point mutations. However, As could also alter DNA repair and produce changes in DNA methylation, and cell cycle. Besides, As increases oxidative stress and decreases the intracellular level of antioxidants (Rossman et al., 2002). It is not clearly understood if the damage caused by chronic exposure to As

Fig. 2. A. 61-year-old male with a chronic non-healing traumatic ulcer related to sharp cusps diagnosed as an invasive squamous cell carcinoma located on the lateral margin. The patient drank arsenic contaminated groundwater for over 18 years. B, C. Both patients were young adult males without tobacco or alcohol consumption. They worked in rural areas in contact with toxic substances such as pesticides, and registered over ten years of arsenic contaminated groundwater consumption. D. 80-yearold female with a tongue lesion diagnosed as OSCC. She was exposed to arsenic water for 20 years. The lesion was associated with prosthetic mechanical irritation and parafunctional habits. 
could be enough to trigger per se neoplastic events. Interestingly, OSCC patients presented here did not show high frequencies of classic risk factors such as alcohol and tobacco consumption. Almost half of the patients had an association with CMI, being a conditioning factor of the site of the lesion development. Figure 2A shows the case of an OSCC which arises from a non-healing chronic traumatic ulcer in relation to sharp cusps in a patient with parafunctional habits. In patients with DNA damage associated with As, the presence of a persistent stimulus, that induces cellular

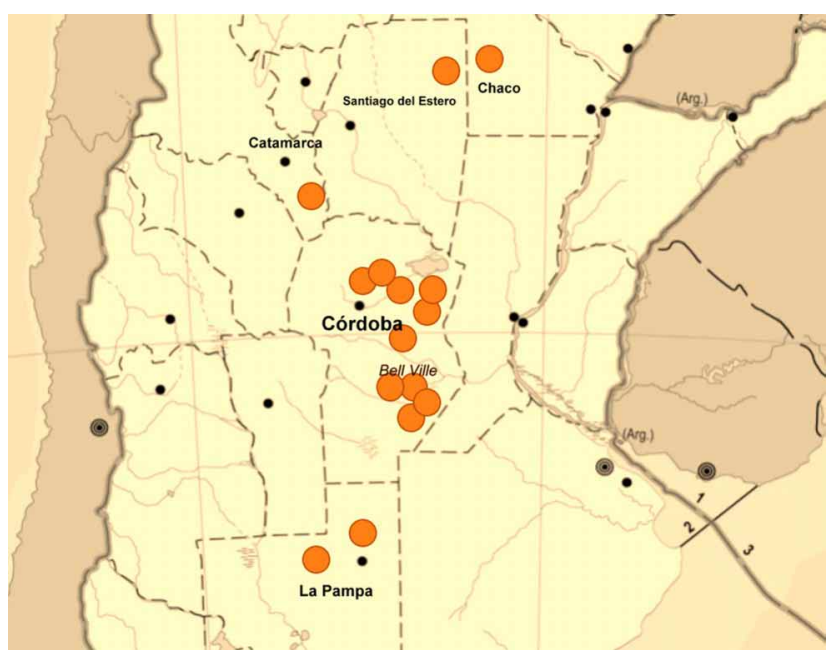

Fig. 3. Geographical distribution of OSCC cases associated with As exposure. proliferation and chronic inflammation such as CMI, would generate the required conditions for tumor promotion and progression, of an oral carcinogenesis multistep model. Other proposed mechanism that linked As and oral carcinogenesis was related to an immunosuppression effect due to its ability to decrease the oncological immune vigilance by altering biological pathways of lymphocytes stimulation and proliferation (Rossman et al.). This co-carcinogenic mechanism would explain the relationship with HPV-associated OSCC in As contaminated Asian countries (Pal \& Halder, 2019). However, due to the retrospective nature, the relationship with oral HPV infection could not be fully evaluated in our study. Further research is needed to explain this possible relationship.

As accumulates in the liver, spleen, gastrointestinal tract, and hard tissues such as bone, competing with the phosphate group in hydroxyapatite crystals, forming apatite-arsenate and other arsenate crystals. Different studies have shown that in the context of bone diseases such as Paget's disease, the As poisoning of the bone tissue, generates an imbalance of bone remodeling, and the increase in osteoblasts oxygen free radicals (Dani, 2013; Chiu et al., 2016; Rodríguez \& Mandalunis, 2018). Interestingly, the most frequent site of OSCC in this cohort of patients was the gingiva and alveolar ridge followed by the tongue margin. The presence of different bacteria

Table I. Clinico-pathological features of the 15 OSCC cases included.

\begin{tabular}{|c|c|c|c|c|c|c|c|}
\hline Sex & Age & Location & $\begin{array}{l}\text { Tobacco } \\
\text { (cigarettes } \\
\text { smoked) }\end{array}$ & Alcohol & Mechanical Irritation & $\begin{array}{l}\text { Years of } \\
\text { arsenical } \\
\text { exposure }\end{array}$ & $\begin{array}{c}\mathrm{T} \\
(\mathrm{TNM})\end{array}$ \\
\hline M & 57 & Soft palate & 438000 & $\begin{array}{l}\text { Heavy } \\
\text { Drinker }\end{array}$ & - & 13 years & T3 \\
\hline M & 65 & Oral mucosa & 146000 & $\begin{array}{l}\text { Heavy } \\
\text { Drinker }\end{array}$ & Yes - Dental CMI & 18 years & $\mathrm{T} 2$ \\
\hline $\mathrm{F}$ & 89 & Gum & - & - & - & 20 years & $\mathrm{T} 1$ \\
\hline M & 77 & $\begin{array}{l}\text { Gum and alveolar } \\
\text { ridge }\end{array}$ & 306600 & $\begin{array}{l}\text { Heavy } \\
\text { Drinker }\end{array}$ & Yes - Dental CMI & 40 years & T3 \\
\hline M & 31 & Tongue margin & - & - & $\begin{array}{c}\text { Yes - Dental CMI (Orthodontic } \\
\text { treatment) }\end{array}$ & 31 years & T3 \\
\hline M & 61 & Tongue margin & 219000 & - & Yes - Dental CMI & 18 years & $\mathrm{T} 2$ \\
\hline M & 59 & Buccal mucosa & - & - & - & 40 years & $\mathrm{T} 1$ \\
\hline M & 44 & Tongue margin & - & - & $\begin{array}{c}\text { Yes - Dental and functional } \\
\text { CMI }\end{array}$ & 40 years & $\mathrm{T} 4$ \\
\hline $\mathrm{F}$ & 80 & Tongue margin & - & - & Yes - Prosthetic CMI & 20 years & $\mathrm{T} 2$ \\
\hline M & 42 & Buccal mucosa & - & - & Yes - Dental CMI & 18 years & T3 \\
\hline $\mathrm{F}$ & 75 & Alveolar ridge & 246000 & - & - & 19 years & T3 \\
\hline M & 76 & Tongue margin & 600000 & $\begin{array}{l}\text { Heavy } \\
\text { Drinker }\end{array}$ & $\begin{array}{c}\text { Yes - Dental and functional } \\
\text { CMI }\end{array}$ & 18 Years & T4 \\
\hline M & 75 & $\begin{array}{l}\text { Floor of the } \\
\text { mouth }\end{array}$ & 116800 & $\begin{array}{l}\text { Heavy } \\
\text { Drinker }\end{array}$ & - & 15 years & $\mathrm{T} 1$ \\
\hline $\mathrm{F}$ & 78 & Gum & - & - & - & 40 years & $\mathrm{T} 4$ \\
\hline $\mathrm{F}$ & 80 & Gum & - & - & - & 20 years & $\mathrm{T} 4$ \\
\hline
\end{tabular}


species known for their ability to release different carcinogenic compounds could generate a local inflammatory microenvironment and consequently a synergism in the carcinogenic effect of As poisoning (Meyer et al., 2008; Hoare et al., 2019). Figure 1A shows an OSCC located on the upper gum related to septic teeth and severe periodontal disease in a female who was exposed to As water during 40 years. She had never smoked nor consumed alcohol.

Only two of the 15 patients included in the study presented potentially malignant disorders, and in both cases they developed OSCC in a clinical context of Multifocal Proliferative Leukoplakia, with gingival or alveolar involvement, without the typical risk factors (tobacco and alcohol consumption) (Fig. 2B). In these cases, As was the unique risk factor recorded. Previous local studies had shown a high frequency of white precancerous lesions among patients with $\mathrm{ERCH}$ (Grinspan \& Biagini, 1985). Although OSCC occurs predominantly in people over 45 years of age, in this case series, we found patients below that age range. In two cases particularly (aged 44 and 31 years old), OSCCs were located on the tongue's lateral margin and the patients did not show classic risk factors (Fig. 2B,C). However, it was recorded that they worked and lived in rural areas (in contact with agrochemicals and pesticides), and consumed As-contaminated groundwater for more than ten years. In these cases, the synergism between exposure to As and agrochemicals (pesticides), could have generated a multiplier effect along the oral carcinogenesis process.

Clinical features and risk factors for OSCC analyzed in this study could lead to considering individuals who have consumed arsenical waters for more than 13 years (as a minimum), as a group at risk of developing oral malignancies. The exposure to As should be registered in all local studies assessing OSCC. Furthermore, it would be important to identify these patients that could represent a high oncological risk to apply strict follow-up protocols for early diagnosis of suspicious lesions and habit cessation measures (suppression of the co-conditions that may cooperate with As in tumorigenesis: smoking and alcohol cessation, elimination of traumatic factors and CMI, control of periodontal disease, etc.).

\section{CONCLUSION}

The development of OSCC is the final phase of a multistage and multifactorial carcinogenic process and the consumption of water contaminated with As has previously been postulated as a risk factor. In most of the selected cases of OSCC related to As exposure, the patients did not present classic risk factors such as tobacco and alcohol consumption and the chronic exposure to arsenical water for many years would seem to be a conditioning factor independent of other variables. However, more case and control studies should be performed to propose the chronic exposure to As as a risk factor for oral cancer. Therefore, the epidemiological studies carried out in As-contaminated areas that address oral cancer, should always incorporate the record of variables related to As exposure.

Finally, patients who live or lived in Ascontaminated areas, must be followed up regularly for early diagnosis of potentially malignant or malignant lesions and must have regular dental check-ups, and instruction of toxic habits cessation. The high frequency of gum cancer found in this study, should raise awareness for periodontics specialists to perform a careful and thorough periodontal examination and timely referrals to diagnose malignancies early, and thereby avoid unnecessary delays.

LEONARDI, N.; GILLIGAN G, M. \& PANICO R. L. Carcinoma oral de células escamosas asociado con la exposición al arsénico: Una serie de casos de Argentina. Int. J. Odontostomat., 14(4):596-601, 2020.

RESUMEN: Muchas regiones de América del Sur están directamente afectadas por aguas subterráneas contaminadas con arsénico (As). Un alto porcentaje de las muestras de agua tomadas en múltiples áreas de Argentina tenían concentraciones de As superiores al nivel aprobado por la OMS. Esta condición se asociaba previamente con un mayor riesgo de enfermedades crónicas, incluidos diferentes tipos de cáncer. La exposición a largo plazo se propuso como un factor de riesgo para el carcinoma oral de células escamosas (OSCC). El objetivo de este estudio es presentar una serie de casos de pacientes diagnosticados con OSCC que han consumido agua contaminada con As durante más de 10 años. Se obtuvieron datos clínicos del archivo de Historias de registros clínicos del Departamento de Medicina Oral de la Facultad de Odontología, Universidad Nacional de Córdoba y Universidad Católica de Córdoba, Argentina. Se incluyeron 15 casos de OSCC. La relación de género masculino: femenino fue de 2: 1. La edad promedio fue de 66 años (31-89 años). En cuanto a la ubicación, la encía o la cresta alveolar edéntula fue el sitio más frecuente $(6 / 15 ; 40 \%)$, seguido del borde de la lengua. El promedio de años de exposición a las aguas arsenicales fue de 24 años (13 - 40 años de exposición). La mayoría de los casos 
presentados fueron de pacientes no bebedores y no fumadores. El $60 \%$ de los tumores fueron diagnosticados en etapas avanzadas. Los estudios epidemiológicos realizados en áreas contaminadas con As que abordan el cáncer oral siempre deben incorporar el registro de variables relacionadas con la exposición a As. Se debe hacer un seguimiento continuo de los pacientes que viven o que vivieron en áreas contaminadas con As para el diagnóstico temprano de lesiones potencialmente malignas. La alta frecuencia de cáncer de encías en estos casos, debe concienciar a los especialistas en periodoncia para que realicen un examen periodontal cuidadoso y completo.

PALABRAS CLAVE: arsénico, carcinoma oral de células escamosas, factores de riesgo, contaminación, aguas subterráneas

\section{REFERENCES}

Banerjee, N. \& Giri, A. K. Arsenic induced health effects, genetic damage and genetic variants in the population exposed to arsenic through drinking water in West Bengal. Proc. Indian Natl. Sci. Acad., 80(3):565-81, 2014.

Bardach, A. E.; Ciapponi, A.; Soto, N.; Chaparro, M. R.; Calderon, M.; Briatore, A.; Cadoppi, N.; Tassara, R. \& Litter, M. I. Epidemiology of chronic disease related to arsenic in Argentina: A systematic review. Sci. Total Environ., 538:802-16, 2015.

Carabantes, A. G. \& de Fernicola, N. A. G. G. Arsénico en el agua de bebida: un problema de salud pública. Rev. Bras. Cienc. Farm., 39(4):365-72, 2003.

Cardoso, A. P. F.; Al-Eryani, L. \& States, J. C. Arsenic-induced carcinogenesis: the impact of miRNA dysregulation. Toxicol. Sci., 165(2):284-90, 2018.

Carrica, V.; Lanfranchi, H. \& Gendelman, H. Contribución al Estudio de Lesiones Cancerizables de la Mucosa Bucal en Pacientes de Zonas de Hidroarsenicismo Crónico Regional Endémico (H.A.C.R.E.). Tesis Doctoral. Ciudad de Córdoba, Facultad de Odontología, Universidad Nacional de Córdoba, 1999.

Chiu, P. R.; Hu, Y. C.; Hsieh, B. S.; Huan, T. C.; Cheng, H. L.; Huang, L. W. \& Chang, K. L. Osteoblasts activate the Nrf2 signalling pathway in response to arsenic trioxide treatment. Int. J. Biochem. Cell Biol., 79:327-36, 2016.

Dani, S. U. Osteoresorptive arsenic intoxication. Bone, 53(2):541-5, 2013.

Grinspan, D. \& Biagini, R. Chronic endemic regional hydroarsenicism. The manifestations of arsenic poisoning caused by drinking water. Med. Cutan. Ibero Lat. Am., 13(2):85-109, 1985.

Hoare, A.; Soto, C.; Rojas-Celis, V. \& Bravo, D. Chronic inflammation as a link between periodontitis and carcinogenesis. Mediators Inflamm., 2019:1029857, 2019.

Hoffmann, M. \& Tribius, S. HPV and oropharyngeal cancer in the eighth edition of the TNM classification: pitfalls in practice. Transl. Oncol., 12(8):1108-12, 2019.

IARC Working Group on the Evaluation of Carcinogenic Risks to Humans. Personal habits and indoor combustions. Volume 100 E. A review of human carcinogens. IARC Monogr. Eval. Carcinog. Risks Hum., 100(PT E):1-538, 2012.

Meyer, M. S.; Joshipura, K.; Giovannucci, E. \& Michaud, D. S. A review of the relationship between tooth loss, periodontal disease, and cancer. Cancer Causes Control, 19(9):895-907, 2008.
Mondal, D.; Banerjee, M.; Kundu, M.; Banerjee, N.; Bhattacharya, U.; Giri, A. K.; Ganguli, B.; Roy, S. S. \& Polya, D. A. Comparison of drinking water, raw rice and cooking of rice as arsenic exposure routes in three contrasting areas of West Bengal, India. Environ. Geochem. Health, 32(6):463-77, 2010.

Mukherjee, A.; Sengupta, M. K.; Hossain, M. A.; Ahamed, S.; Das, B.; Nayak, B.; Lodh, D.; Rahman, M. M. \& Chakraborti, D. Arsenic contamination in groundwater: a global perspective with emphasis on the Asian scenario. J. Health Popul. Nutr., 24(2):14263,2006 .

Pal, P. \& Halder, A Is there any role of arsenic toxicity in HPV related oral squamous cell carcinoma? Biol. Trace Elem. Res., 188(2):274-83, 2019

Pal, P.; Raychowdhury, R.; Dolai, T. K.; Roy, S.; Dastidar, R. \& Halder, A. Study of arsenic exposure in oral/oropharyngeal carcinoma in West Bengal. Int. J. Occup. Med. Environ. Health, 30(2):2719, 2017.

Park, S.; Bae, J.; Nam, B. H. \& Yoo, K. Y. Aetiology of cancer in Asia. Asian Pac. J. Cancer Prev., 9(3):371-80, 2008.

Piemonte, E. D. Cancer Bucal: Diseño y Evaluación de un Índice de Riesgo Multifactorial. Tesis de Doctorado. Ciudad de Córdoba, Facultad de Odontología. Universidad Nacional de Córdoba, 2015.

Piemonte, E. D.; Lazos, J. P. \& Brunotto, M. Relationship between chronic trauma of the oral mucosa, oral potentially malignant disorders and oral cancer. J. Oral Pathol. Med., 39(7):513-7, 2010.

Rodríguez, J. \& Mandalunis, P. M. A review of metal exposure and its effects on bone health. J. Toxicol., 2018:4854152, 2018.

Rossman, T. G.; Uddin, A. N.; Burns, F. J. \& Bosland, M. C. Arsenite cocarcinogenesis: an animal model derived from genetic toxicology studies. Environ. Health Perspect., 110(Suppl. 5):74952, 2002.

States, J. C. Disruption of mitotic progression by arsenic. Biol. Trace Elem. Res., 166(1):34-40, 2015.

Corrresponding author:

Leonardi, Nicolás

DDS, Asssistant Professor Oral Medicine Department

Dentistry School

Universidad Católica de Córdoba

Temistocles Castellano 1102

Córdoba, ZC:5009

ARGENTINA

Email: nico_leonardi@hotmail.com.ar

Received: 28-03-2020

Accepted: 11-05-2020 